EJSM Vol. 22, 2/2017, ISSN: 2450-8535 | www.wnus.edu..pl/ejsm | D0l: 10.18276/ejsm.2017.22-03 | 21-29

\title{
THEORETICAL COMPONENTS OF INTRA-INDUSTRY SERVICE DEVELOPMENT STRATEGY
}

\author{
MAREK GNUSOWSKI, ${ }^{1}$ ANATOLIY G. GONCHARUK, ${ }^{2}$ ELŻBIETA SKĄPSKA, ${ }^{3}$ \\ OLGA DOMAKUR ${ }^{4}$
}

RECEIVED

ACCEPTED

JEL

CLASSIFICATION

KEYWORDS

ABSTRACT

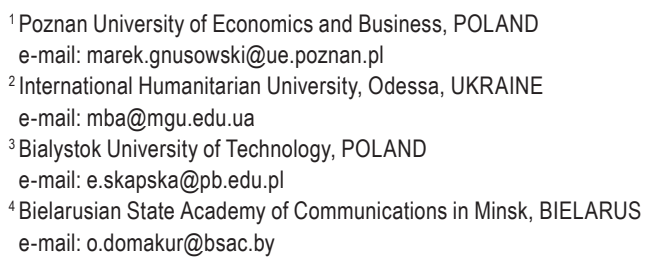

$A 10, B 40,011,012$

service sector, development strategy, economic growth, methodology of development

Presently, the globalization in trade and in capital markets forced service organizations to extend the range of service functions to meet globally accepted standards in a single economic system. However, not all service companies are the same. Globalization has different implications for different types of services and is affected by the nature of the process involved in creating and delivering a given service. The aim of this paper is to define strategies and enduring patterns of action for service sector entities such as: a set of reliable rules, means and reactions as well as to define new methods of performance through analysis and logical conclusions that arise from the laws and dependence between economic values. All the factors have significance in terms of the growth in services thus in the growth of the whole economy in general.

\section{Introduction}

When services lost their local character, the occurrence resulted in the growth of competition and the growth of significance of having skills to search suppliers and select them according to a price offer, supply conditions and quality factors. Such shift has produced dynamic structure transformations and development of services which creates opportunity for new solutions utilized by economic entities on the global market. Creating a single market 
of services is one of the main aims within the scope of improving the economic growth functioning. One can notice incomplete cooperation within movement of products, services and labor force and also stopping the process of expansion (Skapska, 2014).

"A development strategy of intersectoral services" means secluding the service sector from the economy as a whole and establishing rules and goals for the phases of their growth within the sector which naturally affects economic growth. The significance of services in the context of the economic growth has been considerably pointed out in the strategy of the internal market of European Union countries whose main goal is to create a unified service market.

The Lisbon strategy was supposed to be a chance for Europe as for a deepening gap at the level of economic growth in comparison to the United States. However, this method of coordination proved to be ineffective and the year 2020 has been designated as a new destination year (Janger, 2017, pp. 30-42). The new strategy concentrates on three priorities (uniaeuropejska.org, 2017): economic development based on knowledge and innovation; intensification of actions that aim at producing new environment-friendly technologies and improvement of growth conditions for micro, small and medium enterprises; creating new workplaces, investments in improvement of occupational qualifications (courses and trainings) and modernization of employment markets as well as systems of social care.

Under the above-mentioned effort in the key fields that belong to a service sector one may refer to the following detailed goal strategies for services: firstly, actualization of a service market without boundaries and secondly, assisting SME development by helping entities that start up their business activity. Long-term strategies for the year 2020 cover changes in the categories such as: employment, research and development sector (R+D), climate change and balanced use of energy, education and eradicating the poverty and social exclusion. In order to realize each of those goals it is necessary to activate an extended role of services.

Simultaneously, the number of entities that use broadly defined service functions increased. One may admit, that the three-sector theory describing economies is becoming outdated. Thus, the main aim of this article is to propose an intra-industry service development strategy. The study is divided into three parts. The first one concerns key determinants connected with service development. In the second part, we state subjective growth conditions concerning services. The third part includes theoretical context of developing strategies for a service sector.

\section{Contemporapy determinants of service development}

It is imperative to accept the above-mentioned fields as a priority in the union countries which induces the authors to assume an authorial selection of three key factors.

The time of globalization on the economic, social and ecological levels as well as the growth of the ICT sector impose the assumption that the development of services is based on several pillars. The most significant ones may include:

- knowledge,

- service genericness and their specificity (current features distinguishing services from other kinds of activity),

- service sector and service trade liberalization. 


\section{Knowledge as service development pillap}

The basis for a development strategy is knowledge, which is particularly integrated into each stage of a service provision process. Roth and Menor (2003) argue that services theory needs to take a knowledge perspective. Knowledge is considered the most important resource that a firm can control, because firm's knowledge competencies provide value to its customers (Day, Wensley, 1988). Defining knowledge has been changing along with civilizational development, enterprise transformations and evolution of needs of an individual. As Quinn, Anderson and Finkelstein (1996) notice, knowledge may be classified depending on the purpose of its application. Under this criterion one may distinguish strategic knowledge (know-what), practical knowledge (know-how) and theoretical knowledge (know-why). With regard to what knowledge concerns one has catalogue knowledge (it says "what it is"), history knowledge ("the way it was"), process knowledge ("how it happens"), instrumental knowledge ("what decides about it"), scalar knowledge ("how much and how strong").

Service business are incorporated into the business that is based on knowledge, and knowledge is inscribed in the service context. In order to reach rational activity in economy, it is necessary to seek for connections between information economics and service economics (Figure 1).

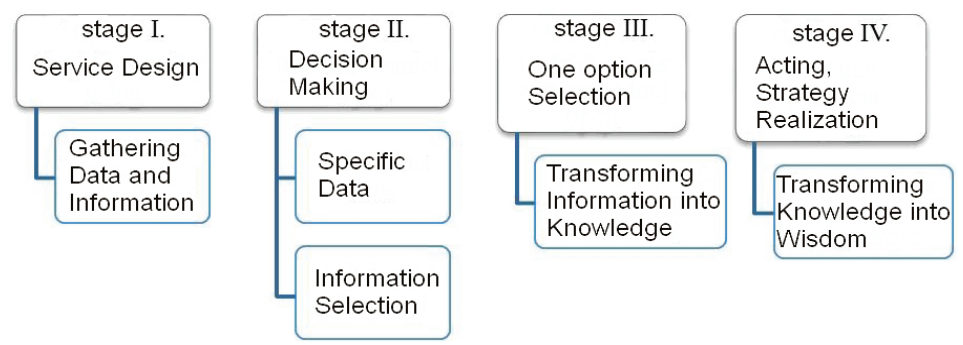

Figure 1. Development stages of service provider's role as inspirer (creator) of growth

Source: own elaboration.

Table 1. Services of high knowledge absorption

\begin{tabular}{cl}
\hline Division & \multicolumn{1}{c}{ Service categories } \\
\hline 61. & Water transport \\
62. & Air transport \\
64. & Post and telecommunication \\
70. & Real estate service \\
71. & Machine and equipment rental \\
72. & Information technology \\
73. & Science \\
74. & Other business services \\
\hline
\end{tabular}

Source: International Monetary Fund (IMF), www.inf.org. 
Considering the methodological approach towards services one should mention the theory of Galbraith (1973) on codependence, coordination and information processing. Although there is progress in programming practices, organizations struggle for introducing methodologies that fit the risk of the design environment. The classification cannot accept the whole as "risky" or "stable" which suggests the need for hybrid solutions (Keih, 2013). Moreover, self-knowledge of a service provider and a service receiver requires reduction to the level of referential knowledge which is a combination of all basic types of knowledge (Rogoziński, 2006, p. 163). Examples of services of high knowledge absorption are shown in Table 1.

They mainly include the high technology service group and apply to "post and telecommunication", "information technology" and "science" groups.

\section{Service genericness and specificity as theip development pillap}

Services represent a diversified group of business activity that is not directly connected with goods production, mining or farm industry. Services usually concern the provision of the value added in the form of human labor, advisory, managing skills, entertainment, training, mediation etc. They are different from other economic activities in many ways (The Service Economy, 2000, p. 7), which may certainly be deemed as a part of the methodological grounds for their development strategy. Moreover, it is widely recognized that all services are not the same. For example, they vary considerably in terms of the nature of a service act and the degree of interaction between a service organization and customers (Storey, Hull, 2010).

We consider the three main categories of services: (Lovelock, 1999)

1. People-processing services that involve each customer directly in delivery of services targeted at the customer's physical person. These services involve physical interactions with customers and necessarily require either that customers travel to the service "factory" or that service providers and equipment come to the customer.

2. Possession-processing services targeted at physical objects belonging to the customer. A local presence is still required when the supplier must come to service objects in a fixed location, such as buildings or large items of installed equipment. However, modern technology now allows certain types of service processes to be administered from a distance through electronic diagnostics.

3. Information-based services - are the most interesting category of services from the standpoint of global strategy development, because they depend on the transmission or manipulation of data in order to create value. The advent of modern global telecommunications, linking intelligent machines to powerful databases, makes it increasingly easy to deliver information-based services around the world.

Genericness of services is important while establishing a strategy. It may be mostly referred to the two main types of services: public services and market services (Tables 2 and 3).

In services, generic strategies could be identified that transcend traditional industry classifications and may prove a fruitful way of dealing with the diversity in services. Moreover, it should be highlighted that, the process of designing services engages various professionals like entrepreneurs, decision makers, designers, managers and strategy builders. 
Table 2. Tree-dimensional set of public service development strategies

\begin{tabular}{|c|c|c|c|c|}
\hline Rationality level & Operation scale & Cause-effect dependency & $\begin{array}{c}\text { Service growth } \\
\text { level }\end{array}$ & Type of service \\
\hline $\begin{array}{l}\text { High } \\
\text { Intellectual capital > expenditure } \\
\text { Middle } \\
\text { Financial capital > employment } \\
\text { Low } \\
\text { Expenditure }<\text { needs }\end{array}$ & MICRO & $\begin{array}{l}\text { The more innovation in } \\
\text { services, the greater } \\
\text { accessibility }\end{array}$ & $1,2,3$ & $\begin{array}{l}\text { Knowledge connected } \\
\text { services: } \\
\text { - Educational services } \\
\text { - Advisory services } \\
\text { - Information services }\end{array}$ \\
\hline \multirow{3}{*}{$\frac{\text { High/Middle/Low }}{\text { Innovation > wastage }}$} & \multirow{3}{*}{$\begin{array}{l}\text { MACRO } \\
\text { Government and representatives }\end{array}$} & \multirow{3}{*}{$\begin{array}{l}\text { The more clear procedures, } \\
\text { the more licenses for growth/ } \\
\text { investment }\end{array}$} & 1 & National defense \\
\hline & & & 2 & State administration \\
\hline & & & 3 & Banking services \\
\hline $\begin{array}{l}\frac{\text { High }}{\text { FDI }>\text { risk }} \\
\text { Middle, low } \\
\text { Product surplus }<\text { storage costs }\end{array}$ & $\begin{array}{l}\text { MEGA } \\
\text { International organizations } \\
\text { Transnational corporations } \\
\text { Integration groupings }\end{array}$ & $\begin{array}{l}\text { The more services in } \\
\text { international flow, the more } \\
\text { openness and bigger condition } \\
\text { scale for operation (expansion) }\end{array}$ & 1 & $\begin{array}{l}\text { Healthcare and social } \\
\text { security }\end{array}$ \\
\hline
\end{tabular}

Source: own elaboration.

Tahle 3. Tree-dimensional set of market service development strategies

\begin{tabular}{|c|c|c|c|c|}
\hline Rationality level & Operation scale & Cause-effect dependency & $\begin{array}{c}\text { Service growth } \\
\text { level }\end{array}$ & Type of service \\
\hline \multirow{8}{*}{$\begin{array}{l}\frac{\text { High }}{\text { capital }>\text { work }} \\
\text { Middle } \\
\text { revenue }>\text { costs } \\
\underline{\text { Low }} \\
\text { spending < incomings }\end{array}$} & \multirow{2}{*}{$\begin{array}{l}\text { MICRO } \\
\text { consumers, entrepreneurs }\end{array}$} & \multirow{2}{*}{$\begin{array}{l}\text { The more services, the better } \\
\text { fulfillment of market needs }\end{array}$} & 1 & Higher level services \\
\hline & & & 2 & Lower level services \\
\hline & \multirow{5}{*}{$\begin{array}{l}\text { MACRO } \\
\text { national economy }\end{array}$} & \multirow{5}{*}{$\begin{array}{l}\text { The greater number of services } \\
\text { in economy, the higher level of } \\
\text { economic growth }\end{array}$} & 1 & Business service \\
\hline & & & 2 & IT services \\
\hline & & & 3 & Industry service \\
\hline & & & 4 & Craftsman services \\
\hline & & & 5 & Household services \\
\hline & $\begin{array}{l}\text { MEGA } \\
\text { global consumers, global } \\
\text { entrepreneurs, global economy }\end{array}$ & $\begin{array}{l}\text { The bigger access to services, } \\
\text { the better fulfillment of needs } \\
\text { and higher utility }\end{array}$ & 1 & Trade services \\
\hline
\end{tabular}

Service development levels from 1 to 5 mean susceptibility to reaching effectiveness within the levels of relatively rational choices - low, middle, high in the micro, macro and global scale.

Source: own elaboration.

The most important factors associated with a target market are: size, growth and access to a market (MunozGuarasa, Pajares, 2014).

\section{Service liheralization as service development pillar}

The priority of economic policy in highly industrialized countries is the requirement to liberalize the service sector and thus to free the service trade. The 80 's of the 20th century was the time when people became more interested in the theoretical analysis of the international service trade. The engagement of a service sector into international exchange in economy results in (Langhammer, 2007, pp. 926-928):

- amplifying competition on service markets thus increasing the efficiency in the form of newer, better and less expensive products, 
- reducing costs through the application of static and dynamic economies of scale, through making international production networks entering cheaper, specializations within the comparative advantage, the import of new technologies and the increase of international competitiveness.

Opened markets of the service sector in developing countries are experiencing the increase of foreign enterprise activity as well. Creating common structures for international trade, international payments and international division of work is a reason for decreasing unemployment, starvation, homelessness and builds an opportunity to develop one's own production in a given region thanks to services e.g. tailoring (Dienstlaistungen, 1988, pp. 47-48).

Service trade is increasing faster than commodity trade, especially because there are fewer market barriers. In contrast to the commodity trade there are four modes of the service trade and, according to GATS WTO, they include: cross-border provision (similar to commodity trade), foreign consumption (e.g. tourism), trade presence (e.g. banks) and presence of physical units (e.g. construction, designs or advisory).

The key to expand trade, including services, is to make a technological progress. It enables greater ability to connect service providers with foreign clients in order to facilitate competition, improvement of products, better quality, lower costs and larger efficiency. What is more, a range of discreet "service oriented" products (such as software or easily accessible interactive data bases) grows, which creates an effective medium for collecting and distributing implicit knowledge and information (The service economy, 2000). Moreover, in professional business services there are efficiency and consumer security standards which are maintained by control systems. These services feature bigger competition, which causes the increase of productivity, lower expenses, price markdown and benefits with improved quality as well as financial diversity or flexibility.

\section{Service growth conditions}

Apart from objective conditions for service development which were shown above, it is worth to add subjective growth conditions concerning services. Accordingly, from the general economic point of view, one may consider development strategies and social-economic policies such as: economic freedom, which is the main value of economic liberalism and it is regulated by the law, contemporary liberalism which triggers entrepreneurship, innovativeness and competitiveness. The range of liberties has been the greatest in the countries that were the most determined to introduce system reforms as well as in those that have reached the greatest progress in the process (Rosati, 2015). This group has taken in, most of all, new EU member states, including Poland. The Polish practice of forecasting service development uses only some of the methods of foreseeing the future (econometric prediction) such as:

a) simple statistics extrapolation of the phenomena that were perceived in the past;

b) forecast that is based on an analysis of the demand development and on the service; consumption in other countries, which are characterized by a higher level of economic growth, and on the assumption that an analogical course of the service consumption process will take place in Poland;

c) exploitation based on so-called descriptive models that take into account a certain set of variables which explain the mechanism of correlations ruling the service; development of the past period;

d) normative method that consists in establishing the norms of satisfying the service needs of people;

e) system analysis methods - the degree of usefulness of separate methods changes depending on the time horizon of a forecast. 
While making economic decisions in services it is necessary to notice and take into account factors that hinder repeatability i.e. emotions, human factor dominance and the level of its maturity, professional experience, personality, qualifications etc. Diversity of criteria for the classification inhibits building a universal model/scheme of a rational service provider. Service organizations have to select a mixed array of actions not only from a current client's point of view, but also for obtaining new service receivers. They should use marketing strategies based on the opinions, interests, personalities and adjust their product according to the existing consumer behavior with regard to reaction predictability and maintenance of relatively permanent demeanor (Skąpska, 2009, p. 307). Varied attributes of a service product are a key to drawing potential clients' attention. It is connected with collective cooperation which may be eased due to public policy consulting the features of an innovation process and the sector infrastructure (Aboal, 2015, pp. 277-283).

\section{Development of strategies for service sector in theoretical context}

A source of developing an operation strategy is strategic thinking. It generally covers the following (Hinterhuber, 1986, p. 34):

- perception of alterations in the environment and reacting in a way beneficial to the company,

- alternative thinking based upon the ability to form significant options for operation,

- thinking in variants based on the ability to form diversified strategies for separate areas of the enterprise operation,

- cause-and-effect thinking based on ability to foresee the results of one's made decisions,

- concentrating the situational analysis on the areas that are most significant for the success,

- engaging the operational means into the areas that are most significant for the success,

- concretization of the selected strategic options (polices) with use of operational projects and schemes,

- organizing an enterprise under strategic operational units and coordination; autonomous functioning of separate strategic linking units that pursue common goals,

- use of effective planning, stimulation and control.

Making complicated strategic decisions, requires, according to Kopeikina (2011, p. 24), the need for joining traditional rational methods with innovative techniques of concentration.

Table 4. Key instruments of operation strategies to the benefit of service growth

\begin{tabular}{ll}
\hline \multicolumn{1}{c}{ Service area } & \multicolumn{1}{c}{ Economy area } \\
\hline Competence & R+D sector \\
Trade ability of services & foreign trade \\
Investments & electronic economy \\
Consumption & social welfare \\
Market & economic system \\
Production/provision & accessibility/ private and public sector \\
Motivations & saving possibility and social promotion \\
Human flow & globalization \\
\hline
\end{tabular}

The table parameters from the field of services correspond to the parameters from the field of economy in the context of development which have a direct bearing from the mezo scale (sectors) to macro scale (national and broader).

Source: own elaboration. 
The strategy for a service firm accounts for not only its mission and long-term objectives, but also how it delivers value to its customers in comparison to other firms in the marketplace (Goldstein, 2002). The key instruments of service growth are shown in Table 4.

What is more, according to OECD (The service economy, 2000) - with further amendments - a proper reform of provisions may ease the promotion of new growth areas; government support of industry - by collecting, analyzing and distributing information, donation and other directed financial support.

\section{Conclusions}

The aim of the article, i.e. proposing the intra-industry service development strategy, has been reached by means of analysis and synthesis methods which allowed drawing the following conclusions:

1. Action and operations based on the methodological rationality, concern dilemmas around creating a single development strategy that covers the whole service sector.

2. As it has been proved in the paper, service development is supported on fixed pillars such as knowledge, service genericness, their specificity and service trade liberalization.

3. There is an open question about harmonization of the service growth strategies through the rationality that exists in stiff schemes.

4. The authors assume that the article will become an introduction to further research featuring quantitative examination. It will concern identification of factors that support and limit the development of a service sector.

5. Due to the diversity of this sector it is advisable to classify services according to clear differences within the sector. The division should regard the influence on the growth and the capabilities of producing development strategies in selected service categories, e.g. financial or legal ones.

In conclusion, one should assume then that, in a general theoretical model concerning a strategy of the above services, the most significant variables describing services' susceptibility to attaining a high level of effect are: knowledge absorptiveness, payments and trans-border abilities which express their free activity on the international stage.

\section{Referennees}

Aboal, D., Bravo-Ortega, C., \& Crespi, G. (2015). Innovation in the Services Sector. Emerging Markets Finance \& Trade, 51 (3).

Agenda. Production and Operations management, 12 (2), 145-164.

Day, G.S. \& Wensley, R. (1988). Assessing advantage: a framework for diagnosing competitive superiority. Journal of Marketing, 52 (2), $1-21$.

Dienstleistungen in der Weltwirtschaft. Die Bedutung der Einbeziehung von Dienstleistungen in das GATT für die Dritte Welt (1988). Eine Studie des Starnberger Instituts, Verlag Dienste in Übersee, Hamburg.

Galbraith, J.R. (1973). Designing Complex Organizations. Reading. MA: Addison-Wesley.

Goldstein, S.M., Johnston, R., Duffy, J. \& Rao, J. (2002). The service concept: the missing link in service design research? Journal of Operations Management, 20 (2), 121-134.

Hinterhuber, H.H. (1986). Struktur und dynamik der strategischen Unternehmungsfuhrung. In: Strategische Unternehmensplanung. Heidelberg: Physical.

International Monetury Fund (IMF). Available at: http://www.inf.org.

Janger, J., Schubert, T., Abdries, P, Rammer, Ch. \& Hoskens, M. (2017). The EU 2020 innovation indicator: A step forward in measuring innovation outputs and outcomes? Research Policy, 46 (1), 30-42. 
Keih, M., Demirkan, H. \& Goul, M. (2013). Service - Oriented Methodology for Systems Development. Journal of Management Information Systems, 30 (1).

Kopeikina, L. (2011). Same dobre decyzje. Poznań: Rebis.

Langhammer, R.J. (2007). Service Trade Liberalization as a Handmaiden of Competitiveness in Manufacturing: An industrialized or Developing Country Issue? Journal of World Trade, 41 (5).

Lovelock, Ch., (1999), Developing marketing strategies for transnational service operations. Journal of Services Marketing, 13 (4/5), 278-295.

Munoz-Guarasa, M. \& Pajares, E. (2014). Determinant Factors in the Internationalization of Knowledge-Intensive Services in a Peripheral Area. Journal of Service Science and Management, 7 (2), 144-164.

Quinn, J., Anderson, D. \& Filkelstein, S. (1996). Managing Professional Intellect: Making the Most of the Best. Harvard Business Review, March-April.

Rogoziński, K. (2006). Kontekstualizacja wiedzy o/w usługach, albo od samowiedzy do wiedzy referencyjnej. In: K. Rogoziński (ed.), Marketing usług profesjonalnych. Usługi bogate w wiedzę. Poznań: Infomila.

Rosati, D. (2015). Synteza raportu. Available at: http://www. forumekonomiczne.pl (1.03.2015).

Roth, A.V. \& Menor, L.R. (2003). Insights into service operations management: a research.

Skapska, E. (2009). Percepcja usługobiorcy w rozwoju społeczeństwa wiedzy. In: E. Skrzypek, A. Sokół (eds.), Zarządzanie kapitałem ludzkim w gospodarce. Warszawa: Instytut Wiedzy i Innowacji.

Skapska, E. (2014). Development of the Service Sector in Poland at the turn of the century. Tendencies, determinants, perspectives. LAP Lambert Academic Publishing, Saarbrücken.

Storey, Ch. \& Hull, F. (2010). Service development success: a contingent approach by knowledge strategy. Journal of Service Management, 21 (2), 140-161.

The service economy, STI S Business and Industry Policy Forum (2000). Organization for Economic Co-operation and Development (OECD), France, No. 80637, 11 May.

Unia Europejska (2017). Available at: http://www.uniaeuropejska.org/strategia-europa-2020 (27.03.2017).

Cite this article aS: Gnusowski, M., Goncharuk, A.G., Skapska, E., Domakur, O. (2017). Theoretical components of intra-industry service development strategy. European Journal of Service Management, 22 (2), 21-29. DOI: 10.18276/ejsm.2017.22-03. 